\title{
Sussex Spaniel
}

National Cancer Institute

\section{Source}

National Cancer Institute. Sussex Spaniel. NCI Thesaurus. Code C53878.

The Sussex Spaniel is a strong, massive dog with loose skin and heavy long ears that are somewhat reminiscent of a Basset Hound. The coat is flat or slightly wavy without being curled and comes in a golden-liver color. The legs, undersides and tail are feathered. Height: 15-16 inches (38-40 cm.) Weight: 40-44 pounds (18-20 kg.) 